\title{
FERTILITY VARIATION AND EFFECTIVE POPULATION SIZE IN A TEAK CLONAL SEED ORCHARD
}

\author{
Sumardi ${ }^{1}$
}

\begin{abstract}
A 27 year old clonal seed orchard of teak (Tectona grandis L.f) in Padangan, East Java comprising 24 clones, was evaluated for fertility, offspring diversity, and genetic drift. Flower and fruit productions were used to assess clone fertility in the orchard. Fertility variation measured as 'sibling coefficient' was found to be 1,62 , having high genetic diversity $(0,97)$ and low coancestry $(0,03)$. The clones varied in fertility in which, $25 \%$ of the most fertile clones in the orchard contributed to $47,5 \%$ of flower and fruit yields. Effective population size in the orchard was 15 , indicating that 15 of the clones contributed effectively to seed yield. Separating on the amounts of seeds that can be collected, individual collection, and proportional mixing of seed per clone might be useful in restricting over representation of highly reproductive clones thereby increasing genetic diversity in the seed crop. Another way to improve seed yield in the orchard is by increasing the effective population size. Thinning or prunning on highly reproductive clones might be useful in increasing effective population size.
\end{abstract}

Keywords : Tectona grandis, clonal seed orchard, fertility variation, coancestry, population size

\section{INTRODUCTION}

Teak (Tectona grandis L.f.) is a native species in Southeast Asia, and distributes naturally only in the Indian Peninsula, Myanmar, Northern Thailand and Northwestern Laos along the northern Thai border (Troup, 1921), and Burma (Laskar, et al., 1985). It grows at latitude $9^{\circ} \mathrm{S}$ (in Myanmar) to $25^{\circ} \mathrm{N}$ (in India), and longitude $70^{\circ}-100^{\circ} \mathrm{E}$ (Rachmawati, et al., 2002). In Indonesia, teak has been planted in Java Kangean, Bali, Muna, Buton, Wetar, Sumbawa and Lampung (Sumarto and Suhaendi, 1985). It is not clear whether teak is native species in Indonesia or introduced from India (Hedegart, 1976 in Soeseno, et al., 1993; Simatupang, 2001). It has been reported that Indonesian has the largest teak plantation in the world, where most of the area is managed by Perum Perhutani a state owned enterprise (Soeseno, et al., 1993).

In 2005, the Indonesian teak demand was around of 2.4 million $\mathrm{m}^{3}$. However, Perum Perhutani could only supply for $400,000 \mathrm{~m}^{3}$ (Iskak, 2005). Althought some can now be provided by community forest such or Java, South and South East Celebes, and East Nusa Tenggara) (Hardiyanto and Prayitno, 2008). Perum Perhutani has endeavored

\footnotetext{
${ }^{1}$ Forestry Research Institute of Kupang Jl. Untungsurapati No.7 (Belakang) Airnona Kupang, NTT.

Email :sumardi_184@yahoo.com.
} 
to improve teak productivity by replanting program on the selected site. To support the program adequate, good quality and timely available seeds are needed in 2010, Perum Perhutani has a target to produce $18,817,916$ seedlings (equal to $21,880 \mathrm{~kg}$ seeds) from clonal seed orchards (CSOs), while the seed harvesting was targeted at $17.000 \mathrm{~kg}$ only. There is still a lack of 4,880 kg of teak seeds (Perum Perhutani, 2010). The main source of teak seeds in Indonesia is seed production areas (SPAs). The fruit production from CSOs has also been used to supply the demand since 1991, but an adequate fruit supply is still lacking (Palupi and Owens, 1998). The productivity of seeds in CSOs is categorized very low in Indonesia, only 0,1 - 0,5 kg per tree (Palupi and Owens, 1998).

The low fruit to flower ratio is generally found in plants which exhibit selfincompatibility. Teak is primarily an out-crossing species, but self-pollination is possible. The extent of self-incompatibility in teak varies from 96 to $100 \%$, and commonly less than $1 \%$ of self-pollinated flowers develop into fruits (Hedegart, 1976 in Tangmitcharoen and Owens, 1997). In teak, pollination success was $78 \%$, but there was low fruit set, only $3-5 \%$ (Tangmitcharoen and Owens, 1997). Another cause of low fruit set was position of fruit and flower within the inflorescence making them easy to abortion (Bawa and Webb, 1984). The papillate stigma is receptive from 11.00 to $13.00 \mathrm{hr}$ with a high temperature causing it dry earlier, and of flowering teak occurs in the rainy season with low pollinators activity (Tangmitcharoen and Owens, 1997).

Despite several problems in fruit production, seedling continues to be used as major planting material in Thailand, Indonesia and India (Kjaer, et al., 2000). It is thereby needed enough quantity of seeds for operational teak plantation. In addition, CSOs manager need to consider the status of seed genetic diversity to maintain sufficient level of offspring genetic diversity and reduce genetic drift impact.

It is cear that, we need to increase the CSOs seed production, with maintaining offspring genetic diversity. The efforts can be done with presciently of fertility, effective population size and genetic diversity of the parent trees. For this reason this study was carried out with aims to (1) quantify the production of fruits and flowers, fertility variation among clones, effective population size and (2) estimate parent trees genetic diversity of teak CSOs in Padangan.

\section{MATERIALS AND METHODS}

\section{A. Data Collection}

Data were collected from a 41.9 ha of teak CSOs in Padangan on November 2009 to June 2010. The orchards were establihed in 1983, which was devided into eight blocks and each block comprised 24 trial clones. Data on flower and fruit productions were collected from 96 sample trees grown in four blocks representing different field conditions. Data were recorded using binocular, camera and handycam in several inflorescences. The number of inflorescences was counted for each tree. Estimates of 
the number of fruits and flowers per tree were obtained by extrapolating the number of flowers and fruits bearing inflorescences per tree.

\section{B. Fertility Variaton}

The male and female fertility of a tree is considered to be proportional to the number of male and female gametes produced by the tree (Gregorius, 1989). Gender fertilities were assumed to be equal to the number of reproductive structures (male fertility as the number of flowers and female fertility as the number of fruits) expressed as a proportion of all trees. Total fertility of a tree (or a clone, parent or genotype) (pi) was taken as the average of the male (mi) and female (fi) fertilities of each tree. When equal number of fruits is collected from each tree, the female fertility is assumed to be constant, equal to $1 / \mathrm{N}$, where $\mathrm{N}$ is the census number of trees in the orchard (Varghese et al., 2006).

Sibling coefficient $(\Psi)$ is the probability that two genes randomly drawn from the gamete gene pool originating from the same parent compared to the probability if the parents having equal representation (Kang and Lindgren, 1999). Thus, $\Psi=1$ means that there is an equal contribution of individual to gamete gene pool in the population. Sibling coefficient, which is used to describe fertility variation, is calculated from the number of clones in the orchard $(\mathrm{N})$ and individual fertility (pi) of each clone (Kang and Lindgren, 1998; 1999):

$$
\psi=N \sum_{i=1}^{N} p_{i}^{2}
$$

A maternal sibling coefficient $\left(\Psi_{f}\right)$ and a paternal sibling coefficient $\left(\Psi_{m}\right)$ can be given as (Kang and El-Kassabi, 2002):

$$
\begin{aligned}
& \psi_{f}=N \sum_{i=1}^{N} f_{i}^{2} \\
& \psi_{m}=N \sum_{i=1}^{N} m_{i}^{2}
\end{aligned}
$$

\section{Effective Population Size}

Group coancestry $(\mathrm{H})$ is the probability that two genes chosen randomlly from a gene pool identical by descent (Cockerham, 1967). If the trees are non related and non-inbred, all pair coancestries are equal to zero and all self coancestries are equal to 
0.5 and the group coancestry is calculated using the methods from Lindgren and Mullin (1998) in Varghese et al. (2006):

$$
\Theta=0.5 \sum_{i=1}^{N} p_{i}^{2}
$$

The effective population size $\left(N_{p}\right)$ is independent of how parents are related or inbred, the status number depends on the relatedness of the parent. It is practical to have a unique term for effective number based on fertility variation among parents only. $N_{p}$ is equivalent to the status number $\left(\mathrm{N}_{\mathrm{s}}\right)$ of a seed orchard where clones are unrelated and non-inbred (Lindgren and Mullin, 1998 in Varghese, et al., 2006). $N_{p}$ is calculated as follows (Kang and Lindgren, 1999):

$$
N_{p}=\frac{N}{\psi}
$$

The effective number of parent is divided into the effective number of female parent $(N p(f))$ and that of male parent $(N p(m))$. The effective number of female $(N p(f))$ and male $\left(N_{p}(m)\right)$ parents can be estimated from eq $(5)$ by substituting female $(\phi f)$ and male $(\phi m)$ sibling coefficients in place of total fertility variation $(\Psi)$ (Kang and ElKassaby, 2002).

The relative population size $(\mathrm{Nr})$ can be used to relate the equally contributing trees to the actual number of trees in the sampled population (Kang, et al., 2001). If all trees are fertile and equally fecund $(\Psi=1)$ the relative population size of the parents becomes equal to one.

$$
N_{r}=\frac{1}{\psi}
$$

Variance effective population size $\left(N_{e}^{(v)}\right)$ is the size of an ideal population with the same sampling variance of allelic frequencies per generation as between the parent genotypes and their offspring. It is calculated as follows (Kang and Lindgren, 1998).

$$
N_{e}^{(v)}=\frac{N}{\psi-1}
$$


The value was also used to express the rate of changes in predicted gene frequencies between the parent trees and their seed crop (Kang et al., 2001).

\section{Genetic Diversity}

Expected gene diversity (GD) is a function of the group coancestry and can be calculated in the orchard relative to a reference population. The reference population, which is a teak clonal seed orchard where that the plus trees were selected from, is considered to have very low group coancestry as it has an infinite number of unrelated individuals in its calculation. (Varghese et al., 2006):

$$
\mathrm{GD}=1-\Theta
$$

Group coancestry can be seen as the fraction of gene diversity lost since tree breeding was initiated.

\section{RESULTS AND DISCUSSION}

\section{A. Results}

1. Reproduction and growth

The average dbh of the teak CSOs in Padangan was $42.4 \mathrm{~cm}$, with the biggest value was $55.1 \mathrm{~cm}$ (clone 18) and the smallest value was $35 \mathrm{~cm}$ (clone 2) (Tabel 1). The value, however, did not differ significantly among clones.

The number of inflorescences, flowers and fruits produced varied among clones. The average inflorescences per clone varied from 10 (clone 7) to 53 (clone 2). The number of flowers varied from 17.725 (clone 7) to 165.053 (clone 2). The number of fruits produced varied from 4 (clone 5) to 783 (clone 3 ). The number of inflorescences, flowers, and fruits produced differed significantly $(p<0,0001)$ among clones. Fruitset differed significantly $(p<0.0001)$ among clone and varied from $0.02 \%$ (clone 5$)$ to $1.66 \%$ (clone 3) (Tabel 1). Observation on the number of inflorescences, flowers and fruits produced was exploited at the same time, so the result could not show early and later flowering clones.

\section{Fertility variation}

The fertile clones were $97 \%$ ramets of 24 clones. Fertility variation varied among clones of the teak CSOs in Padangan. Only two ramets (clone 13) were steril and 25\% of the clones contributed to $47.5 \%$ to the flowers and fruits production. Four clones showed high fertility (three clones contributed to $11 \%$ to the flowers production and 
one clone contributed to $13 \%$ of the fruit production). Fruitset differed significantly $(p<0.001)$ among clones. It was because the flowers producted differed significantly, and the fruits producted from the flowers is generally low.

Table 1 . The average dbh, the number of inflorescences, flowers, fruits and fruitset

\begin{tabular}{|c|c|c|c|c|c|}
\hline $\begin{array}{l}\text { Nomor } \\
\text { Klon }\end{array}$ & $\begin{array}{l}\text { The average dbh } \\
(\mathrm{cm})\end{array}$ & $\begin{array}{c}\text { Inflores- } \\
\text { cences } \\
\text { per tree }\end{array}$ & $\begin{array}{l}\text { Flower } \\
\text { per tree }\end{array}$ & $\begin{array}{l}\text { Fruits } \\
\text { per tree }\end{array}$ & $\begin{array}{c}\text { Fruitset } \\
(\%)\end{array}$ \\
\hline 1 & 38.1 & 39 & 159.179 & 323 & 0.26 \\
\hline 2 & 35.0 & 53 & 165.053 & 46 & 0.03 \\
\hline 3 & 45.8 & 42 & 43.544 & 783 & 1.66 \\
\hline 4 & 39.5 & 18 & 35.279 & 462 & 1.06 \\
\hline 5 & 39.2 & 11 & 24.891 & 4 & 0.02 \\
\hline 6 & 47.9 & 12 & 46.042 & 13 & 0.03 \\
\hline 7 & 45.4 & 10 & 17.726 & 24 & 0.12 \\
\hline 8 & 37.2 & 24 & 47.770 & 385 & 0.73 \\
\hline 9 & 41.8 & 21 & 60.902 & 332 & 0.48 \\
\hline 10 & 41.2 & 15 & 47.602 & 269 & 0.57 \\
\hline 11 & 43.2 & 18 & 40.597 & 336 & 0.75 \\
\hline 12 & 38.9 & 20 & 78.936 & 433 & 0.55 \\
\hline 13 & 40.8 & 45 & 151.020 & 416 & 0.28 \\
\hline 14 & 40.5 & 21 & 74.912 & 165 & 0.22 \\
\hline 15 & 47.8 & 19 & 67.676 & 335 & 0.50 \\
\hline 16 & 44.4 & 17 & 45.337 & 348 & 0.63 \\
\hline 17 & 39.1 & 10 & 23.135 & 79 & 0.35 \\
\hline 18 & 55.1 & 31 & 56.125 & 146 & 0.21 \\
\hline 19 & 41.5 & 20 & 51.222 & 196 & 0.32 \\
\hline 20 & 46.5 & 15 & 59.539 & 27 & 0.32 \\
\hline 21 & 37.6 & 18 & 46.069 & 156 & 0.35 \\
\hline 22 & 42.1 & 16 & 34.551 & 307 & 0.86 \\
\hline 23 & 43.3 & 10 & 26.149 & 103 & 0.36 \\
\hline 24 & 48.5 & 21 & 63.505 & 265 & 0.37 \\
\hline
\end{tabular}

Fertility variation of the teak CSOs in Padangan as indicated by the sibling coefficient value $(\psi)$ was 1.62 . Male fertility variation $\left(\psi_{m}\right)$ was 1.43 and female fertility variation $\left(\psi_{f}\right)$ was 1.54 (Tabel 2$)$. 
3. Effective population size and genetic diversity

Relative population size $\left(\mathrm{N}_{\mathrm{r}}\right)$ of teak CSOs in Padangan was 0.58 and variance effective population $\left(\mathrm{N}_{\mathrm{e}}^{(\mathrm{v})}\right.$ ) was 38.8 (Table 2 ). The high fertility variation of male as indicated by the male sibling coefficient caused low value of $\mathrm{N}_{\mathrm{r}}$ and $\left(\mathrm{N}_{\mathrm{e}}^{(\mathrm{v})}\right)$ was low.

Table 2. Fertility variation, genetic diversity and variance effective population size

\begin{tabular}{lccc}
\hline \multicolumn{1}{c}{ Trait } & Male $(m)$ & Female $(f)$ & $\begin{array}{c}\text { Combined } \\
\text { Fertility }\end{array}$ \\
\hline Sibling coefficient $(\psi)$ & 1.43 & 1.54 & 1.62 \\
Genetic diversity $(\mathrm{GD})$ & 0.97 & 0.97 & 0.97 \\
Effective population size $\left(\mathrm{N}_{\mathrm{c}}\right)$ & & & 38.81 \\
Variance effective population $\left(\mathrm{N}_{\mathrm{c}}^{(\mathrm{v})}\right)$ & & & \\
\hline
\end{tabular}

Coancestry $(\Theta)$, effective population size $\left(\mathrm{N}_{\mathrm{p}}\right)$, and genetic diversity (GD) of teak clonal seed orchard in Padangan were 0.03, 15 and 0.97 respectively (Table 2).

\section{B. Discussion}

1. Fertility

A general lack of flowering in CSOs resulted in considerable fertility variation between clones (Kjaer, 1996 in Varghese, et al., 2006). Although site has a marked effect on flowering habit (early flowering is observed in dry sites) of trees, fertility is reported to be strongly inherited (Kaosard, 1996 in Varghese, et al., 2006) and the proportion of non-flowering clones may be high during low flowering years (Nikkanen and Ruotsalainen, 2000). The flowering season occurred in the long time when the research conducted in Padangan. It was because higher number of clones produced flowers, but only few clones produced fruits.

Low fruitset in nature may be large due to a high incidence of self-pollination and a high level of self-incompatibility, but several other factors, such as resource limitation and position of fruit within inflorescence may also cause (Bawa and Webb, 1984). Selfincompatibility and abortion of selfed seed often result in 1-2\% seedset (Kaosard 1996) under natural conditions. An average fruitset of teak CSOs in Padangan was 0,43\%, that is lower than under natural conditions $(1-2 \%)$.

The number of ramet in fertile indicates that there was genetic diversity contributed in balance of offspring and cross breeding. However, more the number of ramet in fertile was not followed by flowers produced, so the possibility of cross breeding was still limited. In Padangan, different gamete contribution resulting from over representation 
of a few clones would lead to differences in genetic constitution of seed crop. Few of the fertile clones largely contributed to the flower and fruit production with about 25\% of clones producing almost $47.5 \%$ in flowers and fruits production. As a comparison, research at the Namaacha Arboretum in the south of Mozambique, reported 55\% gamete contribution from $20 \%$ of the most fertile trees in a teak stand (Bila et al., 1999). The Pinus koraiensis seed orchard at Walayar showed an unbalanced representation of clones in seed production as indicated by the sibling coefficient (Kang and Lindgren, 1999). An unbalanced representation of clones in seed production may not only be caused by fertility variation but olso misslabelling the clones. Relatively high levels of errors were observed showing that $16 \%$ ramets and $40 \%$ clones analysed were mislabelled with Glutamate Oxalacetate Transaminase (GOT) (Iskandar et al., 2003).

The average sibling coefficient value $(\psi)$ at the teak CSOs in Padangan was 1.62, indicating that there was a deviation of 1.62 times from random mating to inbreeding, when all clones would have contributed equally. Relative population size $\left(\mathrm{N}_{\mathrm{r}}\right)$ of teak CSOs in Padangan was 0.58 and variance effective population $\left(\mathrm{N}_{\mathrm{e}}^{(\mathrm{v})}\right)$ was 38.8 . Relatively higher $\mathrm{N}_{\mathrm{e}}^{(\mathrm{v})}$ in Padangan than in the teak CSOs-I and CSOs-II in Western Ghats region of peninsular India (20.99 and 2.73, respectively). Which caused relatively lower genetic drift in Padangan than in Western Ghats region of peninsular India. Plantation established from high fertility variation seed source would have high coancestry and relatedness.

If all clones of teak CSOs in Padangan contributed equally, each clone would have contributed about $4.17 \%$ of the total fruits produced. The actual contribution differed significantly between clones in ranges from $0.06 \%$ to $13.16 \%$, indicating differences in fertility pattern of the orchards. The low fruit production of teak CSOs in Padangan was not only caused by fertility variation between clones but also by natural factor likes rainfall.

\section{Genetic diversity and population size}

Unequal gamete contribution by orchard clones can has an important bearing on gene diversity of orchard progeny. Effective clone number indicates the number of clones that contribute uniformly to the gamete pool. Relatively small number of clones in orchards and substantial difference in fertility have resulted in high levels of coancestry even in the first generation. Effective population size $\left(\mathrm{N}_{\mathrm{p}}\right)$ of teak CSOs in Padangan was 15 , indicated that there was 15 unrelatedness of clones that contributed uniformly to the gamete pool. To avoid mislabelling 15 unrelatedness of clones that contribute uniformly to the gamete pool in the orchard, an investigation on the genotypes of the clones may be needed for future reference. 
Table 3. The average rainfall in a teak clonal seed orchards in Padangan (2008 May 2011)

\begin{tabular}{|c|c|c|c|c|c|c|}
\hline \multirow{3}{*}{ Month } & \multicolumn{6}{|c|}{ Year } \\
\hline & \multicolumn{2}{|c|}{2008} & \multicolumn{2}{|c|}{2009} & \multicolumn{2}{|c|}{2010} \\
\hline & $\mathrm{rw}(\mathrm{mm})$ & $\begin{array}{c}\mathrm{rd} \\
\text { (days) }\end{array}$ & $\mathrm{rw}(\mathrm{mm})$ & $\begin{array}{c}\mathrm{rd} \\
\text { (days) }\end{array}$ & $\mathrm{rw}(\mathrm{mm})$ & $\begin{array}{c}\mathrm{rd} \\
\text { (days) }\end{array}$ \\
\hline Januari & 26 & 8 & 230 & 10 & 280 & 19 \\
\hline Februari & 47 & 12 & 270 & 12 & 360 & 17 \\
\hline Maret & 34 & 7 & 182 & 8 & 253 & 15 \\
\hline April & 42 & 7 & 75 & 3 & 310 & 12 \\
\hline Mei & 17 & 3 & 345 & 17 & 132 & 10 \\
\hline Juni & 0 & 0 & 37 & 4 & & \\
\hline Juli & 0 & 0 & 15 & 1 & & \\
\hline Agustus & 0 & 0 & 0 & 0 & & \\
\hline September & 0 & 0 & 0 & 0 & & \\
\hline Oktober & 218 & 10 & 54 & 2 & & \\
\hline November & 126 & 10 & 850 & 8 & & \\
\hline \multirow[t]{2}{*}{ Desember } & 364 & 12 & 798 & 10 & & \\
\hline & 874 & 69 & 2,856 & 75 & & \\
\hline
\end{tabular}

Note: rw : rainwater; rd : rainy day

Establishment of vast area of seed source from the teak CSOs in Padangan with low fruits production would result in bad plantation, if no treatment applied the seed harvesting. Limiting the number of seeds harvested from individual clones is the option to improve diversity of orchard progeny (Kang et al., 2003 in Varghese, et al., 2006). Genetic diversity of the teak CSOs in Padangan would remained when seeds harvested from individual clones. However could only be done in productive clones, and mix of the same number of seeds from each clone. Teak CSOs would be better when more number of effective clones (20 - 25 clones) used for starting establishment (Zobel and Talbert, 1984).

\section{Implications of gene diversity in Teak CSOs}

Breeding programs should utilise efficient techniques to maximise gain at the expense of genetic diversity in production populations. Conservation stands and clone banks are also important to conserve diversity, which is essential for sustained improvement in advanced generations (Suangtho et al., 1999 in Varghese, 2006). This is especially true for a long rotation species with large variation in fertility and tendency for low fruit 
production. Even in production orchards, maintaining adequate effective population size would be important for reducing selfing and production of out crossed seed.

As a reduction in the effective population size is inevitable in a domestication process, efforts should be made to start with desirable levels of diversity in the first generation. High variability in parental or each clone contribution would mean substantial loss of diversity in the first generation. Sufficient diversity (effective contribution of clones) and synchrony in flowering would be essential for production of vigorous out crossed seed with reduced pollen contamination from inferior sources to obtain anticipated gain from orchards. In ideal conditions, a good clonal seed orchard of teak is expected to provide $25 \%$ gain (after progeny testing and genetic thinning) over the local planting stock (Kjaer et al., 1999). Teak has an inherent problem of flower abortion and low fruitset, Hence, it is important to make that the number of contributing parent trees is high. This is best achieved with low input techniques like seed production areas (Lindgren, 2000 in Varghese et al., 2006).

\section{Considerations for orchard management}

Occurrence of inbreeding depression from self-pollination is low in teak because of adaptations like self-incompatibility (Hedegart, 1976 in Varghese et al., 2006). This would also lead to poor fruitset due to inadequate pollen supply, sexual asymmetry and unbalanced parental contribution. The orchard manager can adopt corrective measures to reduce the magnitude of undesirable effects of fertility variation. Making collections with ramet and clone identity and mixing them in an equal proportion would keep the coancestry in low level. If improvement in diversity level were inadequate as in case of teak CSOs in Padangan, intentional adjustment of ramet numbers of each clone would be the next measure (Kang et al., 2001). This step can modify the total fertility status of a clone as in case of teak CSOs in Padangan. It could be achieved either by total removal of some ramets of the clone if the fertility status is highly skewed or by just retaining them as pollen producers (Varghese et al., 2006).

Another measure that can be adopted to increase gene diversity is to mix seeds from different seed orchards (Chaisurisri and El-Kassaby, 1993). These measures can help to reduce the loss of gene diversity during domestication. As fertility variation can be high in poor flowering years, seed collection may even be avoided during those years to avoid genetic drift (Kjaer, 1996).

Selection of suitable sites and clones for an orchard assume great importance. Locating orchards on hill slopes under dense forest areas may affect light availability, and heavy stocking with close spacing would not be conducive for flowering in teak.

Majority of teak orchards have been established with a few clones (Varghese et al., 2006) selected purely for yield and tree form. Low fruits produced from the teak CSOs caused by without considering effective clone number based on fertility status and outcrossing occasion. The effective clone number of $20-25$ clones (Zobel and Talbert 
1984), would give more opportunity in outcrossing, and reduce low fruits producing of self-incompatibility impact, and also keep the genetic gain. As large variation in flowering is observed at population and individual tree levels, fertility is one of the most important traits assessed in provenance, progeny and clonal trials (Keiding et al., 1986 in Varghese, et al., 2006). It would be ideal to plan an orchard in terms of its effective clone number based on fertility status of the trees selected for a location.

\section{Seed orchards for domestication}

As genetic diversity is an important requirement for successful regeneration of teak, reduction in diversity with each generation would be a major factor that has to be managed effectively. Moreover, since plantation rotation period is long, the impact of selections made in one generation is felt only after a long period, by which time the options for further phenotypic improvement would be limited. Thus, a low input strategy with emphasis on diversity during selection would be ideal to carry forward a new generation. In the other site, CSOs, established with intensively selected trees often employ improvement techniques to maximise gain but clones often vary in fertility (Varghese et al., 2006), and the individual contribution and resultant genetic drift would affect the quality of seed crops and subsequent plantations.

The proportion of non-flowering clones may be high during low flowering years (Nikkanen and Routsalainen, 2000). Maintaining a status number of $70 \%$ of the number of orchard clones or approximately $2 / 3$ of the census number would keep levels of coancestry low and promote out crossing in orchards (Varghese et al., 2006). Selection of clones can be restricted to locations within the same geographical region, as shifting clones across latitudes can affect the synchrony in flowering. Nikkanen and Ruotsalainen (2000) reported a decrease in male fertility with increasing latitude of origin of clone in Picea abies.

Establishment of vast areas of teak clonal seed orchards without considering fertility and fecundity status of the clones has proved futile (Nicodemus et al., 2000), as fertility is seen to be quite erratic and influenced by site and provenance effects. If, however, bud grafting selected in good trees are used for establishing clonal seed orchards in similar environments the gain and diversity obtained can be improved with considering fertility and fecundity status of the clones. Increasing seed production in teak clonal seed orchars in Padangan assuming constant fertility status can be done by reducing the number of ramet of high fertility clones. If not possible then thinning canopy (prunning) ahead of the spring on a ramet of clone which has a high fertility should be undertaken. This action is important to avoid the risk of decresing genetic variation in the generation.

\section{CONCLUSION}

An average fruitset of teak CSOs in Padangan was $0.43 \%$. There was a deviation of 1.62 times from random mating to inbreeding, indicated that the average of sibling 
coefficient value $(\psi)$ of teak CSOs in Padangan was 1.62 . That was caused by the genetic drift (but only a few (0.03)) with the genetic diversity of 0.97 . The 15 unrelatedness clones contributed uniformly on the gamete pool (in maximum of 24 clones). Which indicated the effective population size of 15 . The effective clone number of $20-25$ clones would give more opportunity in outcrossing, and reduce low fruits producing self-incompatibility impact. Making collection of seed from clones and mixing them in an equal proportion would keep the coancestry levels low and also keep the genetic gain.

\section{ACKNOWLEDGEMENTS}

The author is very grateful to Prof. Moh. Na'iem, Dr. Eko Bhakti Hardiyanto for their invaluable comments and supports. Thanks also due to Hermawan, S.Hut., Maksum, Waras, Suyitno, Muntolib, Karmin, Wakhid and Dodik for their help and support on the field.

\section{REFERENCES}

Bawa, K.S., and Webb, C.J. 1984. Flower, Fruit and Seed Abortion in Tropical Forest Trees: Implications for The Evolution of Paternal and Maternal Reproductive Patterns. American Journal of Botany 71 (5):736-751.

Bila, A.D., D. Lindgren, and T.J. Mullin 1999. Fertility Variation and Its Effect on Diversity Over Generations in A Teak Plantation (Tectona grandis L.f.). Silvae Genetica 48:109-114.

Chaisurisri K. and Y.A. El-Kassaby 1993. Estimation of Clonal Contribution to Cone and Seed Crops in Sitka Spruce Seed Orchard. Annuals of Forest Science 50: 461-467.

Cockerham, C.C. 1967. Group Inbreeding and Coancestry. Genetics 56:89-104.

Gregorius, H.R. 1989. Characterization and Analysis of Mating Systems. Ekopan Verlag, Germany, pp 158.

Hardiyanto, E.B. and T.A. Prayitno 2008. Present Utilization of Small-Diameter Teak Log from Community Teak Plantations in Java and Eastern Indonesia. Technical Report. ITTO Project PPD 121/06 Rev. 2(I). 45pp.

Iskak, M. 2005. Produktifitas Tegakan Jati JPP Intensif sampai Umur 20 Tahun ke Depan. Seperempat Abad Pemuliaan Jati Perum Perhutani. Pusat Pengembangan Sumber Daya Hutan Perum Perhutani:143-153.

Kang, K.S., D. Lindgren, T.J. Mullin 2001. Prediction of Genetic Gain and Gene Diversity in Seed Orchard Crops Under Alternative Management Strategies. Theori Application Genetica 103:1099-1107. 
Kang, K.-S., Y.A. El-Kasabi 2002. Considerations of Correlated Fertility Between Genders on Genetic Diversity: The Pinus Densiflora Seed Orchard as A Model. Theori Application Genetica 105:1183-1189

Kang, K.S., and D. Lindgren 1998. Fertility Variation and Its Effect on The Relatedness of Seeds in Pinus densiflora, Pinus thunbergii and Pinus koraiensis Clonal Seed Orchards. Silvae Genetica 47:196-201.

Kang, K.S., and D. Lindgren 1999. Fertility Variation Among Clones of Korean Pine (Pinus koraiensis S. et Z.) and Its Implications on Seed Orchard Management. Forest Genetics 6(3):191-200.

Kang, K.S., A.M. Harju, D. Lindgren, T. Nikkanen, C. Almqvist, and G.U. Suh 2001. Variation in Effective Number of Clones in Seed Orchards. New Forest 21:17-33.

Kaosard, A. 1996. Teak (Tectona grandis Linn. F.) Domestication and Breeding. UNDP/ FAO. Los Banos, Phillipines. RAS/91/004.

Kjaer E.D. 1996. Estimation of Effective Population Number in a Picea abies (karst.) Seed Orchard Based on Flower Assessment. Scand. J. For. Res. 11: 111-121.

Kjaer, E.D., A. Kaosa-ard, and V. Suangtho 2000. Domestication of Teak Through Tree Improvement. Options, Possible Gains and Critical Factors. In: Enters, T. and Nair, C.T.S (eds.). Site, Technology and Productivity of Teak Plantations. FORSPA Publication No. 24/2000, TEAKNET Publication No.3. pp.161-190.

Laskar, S., S.G. Majumdar, and B. Basak 1985. Isolation and Chemical Investigation of Teak (Tectona grandis Linn.) Seed Proteins. JAOCS 62 No.8:1266-1268.

Nicodemus A, B. Nagarajan, C. Narayanan, M. Varghese, K. Subramanian (2005) Genetic variation in Indian teak (Tectona grandis L.F.) populations assayed through RAPD markers. Indian For 131(9):1121-1131

Nikkanen T. and S. Routsalainen. 2000. Variation in Flowering Abundance and Its Impact on The Genetic Diversity of The Seed Crop in Norway Spruce Seed Orchard. Silva Fenn. 34(3):205-222.

Palupi, E.R., and J.N. Owens 1998. Reproductive Phenology and Reproductive Success of Teak (Tectona grandis L.f.). International Journal of Plant Sciences 159:833-842.

Perum Perhutani. 2010. Distribusi Benih KBK dan Bibit JPP Tahun 2010. Surat Direktur Perncanaan dan Pengelolaan Hutan Perum Perhutani Nomor. 322/052.1/SDH/ Dir, tanggal 28 Juli 2010.

Rachmawati, H., D. Irianto, dan C.P. Hansen 2002. Tectona grandis Linn. Informasi Singkat Benih. Direktorat Perbenihan Tanaman Hutan. Departemen Kehutanan. Jakarta. No.15 Januari 2002.

Simatupang, M.H. 2001. Some Notes on Origin and Establishment of Teak Forest (Tectona grandis L.F.) in Java, Indonesia. In Hardiyanto, E. B. (ed.). Proceedings of 
Third Regional Seminar on Teak, 31 July-5 August 2000. Yogyakarta, Indonesia. Perhutani, TEAKNET and Faculty of Forestry Gadjah Mada University. pp.91-98.

Siregar, U. J. Siregar and S. Siswamartana. 2003. Early Detection of Mislabelled Teak Clones Using Glutamate Oxaloacetate Transaminase (GOT) Marker. In International Conference Quality Timber Products of Teak from Sustainable Forest Management. India.

Soeseno, U.H., Hardiyanto, E.B., Na'iem, M., Winarni, W.W., Suginingsih. 1993. Strategi Pemuliaan Pohon Beberapa Spesies di Perum Perhutani. Tim Konsultan Pemuliaan Pohon Fakultas Kehutanan UGM.

Sumarto, S., dan Suhaendi, H. 1985. Tinjauan Mengenai Program Pemuliaan Jati (Tectona grandis L.f.). Pusat Penelitian Perlindungan Hutan Badan Litbang Departemen Kehutanan. Bogor.

Tangmitcharoen, S., and Owens, J.N. 1997. Floral Biology, Pollination, Pistil Receptivity, and Pollen Tube Growth of Teak (Tectona grandis Linn. f.). Annals of Botany 79:227-241.

Troup, R.S. 1921. The Silviculture of Indian Trees. Oxford Press.

Varghese, M., Nicodemus, A., Nagarajan, B., and Lindgren, D. 2006. Impact of Fertility Variation on Gene Diversity and Drift in Two Clonal Seed Orchards of Teak (Tectona grandis Linn. f.). New Forest 31:497-512.

Varghese, M., Kamalakannan, R., Nicodemus, A., Lindgren, D. 2008. Fertility Variation and Its Impact on Seed Crops in Seed Production Areas and A Natural Stand of Teak in Southern India. Euphytica 160:131-141.

Zobel, B. and Talbert 1984. Applied Forest Tree Improvement. John Wiley and Sons, Canada. 